\title{
Peluang Pemberdayaan Masyarakat melalui Penyediaan Program Lifeskill Game Online Pubg Mobile Di Era Teknologi Informasi Serta Komunikasi Modern
}

\author{
Wahyu Alfi Mu'alif ${ }^{1}$, Ismaniar ${ }^{2}$ \\ Pendidikan Luar Sekolah FIP UNP ${ }^{1}$, Pendidikan LuarSekolah FIP UNP ${ }^{2}$ \\ digimonxmyself@gmail.com ${ }^{1}$, ismaniar.js.pls@fip.unp.ac.id.com ${ }^{2}$
}

Received: 12 Desember 2021; Revised: 31 Desember 2021; Accepted: 31 Desember 2021

\begin{abstract}
This research is motivated by the widespread development of the number of enthusiasts as well as the success and achievements of the online gaming community today, especially since the pandemic period. The phenomenon of the many achievement events and online game competitions also adds to its own attraction for the younger generation, so that many of them want to improve their skills in playing online games. The purpose of the research is to reveal various opportunities that can be captured by the community, especially the younger generation, in the form of offering life skills programs to improve their abilities. This type of research is descriptive, with a literature study approach. Sources of data are obtained from various literatures, books, journals, print and online mass media that are relevant to the research studies that have been determined. The results of the research are that there are several Out of School Education programs that are suitable to be held in response to the high enthusiasm of the online game lovers. including, Private Class, Workshop, Training, and Programmed online game community. The hope is for online game players and organizers of this life skill improvement program to be a means of empowering society in the era of modern information and communication technology.
\end{abstract}

Keywords: Opportunity, empowerment, Lifeskill, information and communication technology era

\begin{abstract}
ABSTRAK
Penelitian ini dilatarbelakangi oleh maraknya perkembangan jumlah peminat serta keberhasilan dan prestasi komunitas game online sekarang ini, terutama sejak masa pandemi. Fenomena banyaknya ajang prestasi dan lomba game online juga semakin menambah daya tarik tersendiri bagi generasi muda, sehingga mereka banyak yang ingin meningkatkan skillnya dalam bermain game online. Tujuan penelitian mengungkapkan berbagai peluang yang dapat di tangkap oleh masyarakat terutama generasi muda dalam bentuk penawaran program lifeskill dalam meningkatkan kemampuannya. Jenis penelitian deskriptif, dengan pendekatan studi literature. Sumber data di peroleh dari berbagai literature, buku, jurnal, media massa cetak maupun online yang relevan dengan kajian penelitian yang sudah ditetapkan. Hasil penelitian ada beberapa program Pendidikan Luar Sekolah yang cocok diselenggarakan menyikapi tingginya antusiasme dari penikmat game online tersebut. diantaranya ,Class Private, Workshop, Training, dan Komunitas game online terprogram. Yang harapannya kepada pemain game online dan penyelenggara program peningkatan life skill ini menjadi sarana dalam pemberdayaan masyarakat di era teknologi informasi dan komunikasi modern.
\end{abstract}

Kata Kunci: Peluang, pemberdayaan, Lifeskill, era teknologi informasi dan komunikasi.

(C2021 by Wahyu Alfi Mu'alif, Ismaniar Under the license CC BY-SA 4.0 


\section{PENDAHULUAN}

Fenomena banyaknya ajang prestasi dan lomba game online juga semakin menambah daya tarik tersendiri bagi generasi muda. Keberadaan game online pada era globalisasi saat ini tidak hanya sebagai sarana hiburan semata yang pada umumnya dianggap sebagai kegiatan yang tidak bermanfaat. Namun juga keberadaan game online yang digemari berbagai kalangan usia tersebut, sudah di legalkan dengan adanya lembaga independent yang menaungi Platform game online yang bernama Federasi E-Sports Indonesia (FEI). Platform ini bisa menjadi peluang usaha serta bisnis untuk menghasilkan secara ekonomi guna untuk memenuhi kebutuhan finansial di era teknologi informasi ini dan pada masa covid 19. Selain sebagai sarana untuk mendapat profit. Kegiatan memainkan game juga merupakan wadah bagi player game untuk menyalurkan hobi serta mengukir prestasi, terlebih pada era digital ini kegiatan bermain game berbasis kompetitif sudah sering diadakan. Banyak sekali komunitas-komunitas game yang sudah terkenal di dunia PUBG Mobile yang menampung para player game tersebut guna untuk terjun ke dunia kompetitif diantaranya merupakan Bigetron E-Sports, Rex Regum Qeon, Evos E-Sports, 69 E-Sports serta masih banyak lagi. Komunitaskomunitas game tersebut ada di setiap region daerah di Indonesia. Tentunya untuk bergabung dengan komunitas game tersebut tidak sembarang orang, melainkan komunitas tersebut memiliki kualifikasi serta persyaratan untuk kemudian bisa bergabung menjadi anggota komunitas.

Berbagai fenomena di atas, memungkinkan munculnya peluang-peluang bagi masyarakat untuk membuka program pendidikan dan pelatihan bagi para peminat game dan player melalui jalur pendidikan non formal. Selanjutnya pada penelitian ini, peneliti mencoba menemukan dan menganalisis berbagai bentuk program pendidikan non formal yang dapat diselenggarakan untuk menjawab kebutuhan generasi muda di era teknologi informasi dan komunikasi, sehingga meningkatkan keterampilan dan pengetahuan mereka sesuai hobi dan kegemaran yang berkembang. 


\section{METODE}

Penelitian ini menggunakan jenis penelitian deskriptif, dengan pendekatan studi literature. Menurut Zed (2008:3) metode studi literatur adalah rangkaian aktivitas tertentu yang berkaitan dengan metode pengumpulan daftar pustaka, mencatat maupun membaca, serta mengelola bahan penelitian. Studi literature merupakan survey serta pembahasan literatur pada bidang tertentu dari sebuah penelitian. Studi ini ialah gambaran singkat dari apa yang telah dipelajari, argumentasi, serta ditetapkan mengenai suatu permasalahan, dan biasanya diorganisasikan secara kronologis atau tematis. Sumber data di peroleh dari berbagai literature, buku, jurnal, media massa cetak maupun online yang relevan dengan kajian penelitian yang sudah ditetapkan

\section{HASIL DAN PEMBAHASAN}

\section{Hasil}

Pendidikan Luar Sekolah merupakan pendidikan yang dilaksanakan di luar sistem persekolahan yang berorientasi pada kebutuhan warga belajar. Menurut Komar (2006) pendidikan nonformal adalah pendidikan yang diselenggarakan di luar sekolah, baik dilembagakan maupun tidak. Penyelenggaraan kegiatan pendidikan ini lebih terbuka, tidak terikat, dan tidak terpusat. Menurut Ideharmida dkk (2018) pendidikan nonformal atau dikenal juga dengan pendidikan luar sekolah hadir dalam bentuk program-program belajar yang fleksibel dalam penyelenggaraan dan memiliki sasaran belajar yang luas, mulai dari anak-anak hingga orang dewasa. Diklus (2010) mengatakan Pendidikan Luar Sekolah adalah setiap usaha pelayanan pendidikan yang diselenggarakan di luar sistem sekolah, berlangsung seumur hidup, dijalankan dengan sengaja, teratur dan terencana yang bertujuan untuk mengaktualisasi potensi manusia. Sehingga dapat mewujudkan manusia yang gemar belajar dan mampu meningkatkan kesejahteraan hidup. Jadi pendidikan luar sekolah yaitu pendidikan yang dilakukan secara mandiri di luar sistem persekolahan memiliki kegiatan yang terorganisir dan teratur untuk melayani masyarakat. Menurut Aini (2006) pendidikan nonformal juga ikut membantu pendidikan, terutama mengatasi anak yang tidak terlayani sekolah, 
putus sekolah, dan pendidikan kemasyarakatan. Jalur pendidikan nonformal memiliki ciri yang diselenggarakan di luar sekolah melalui kegiatan belajar mengajar yang tidak harus berjenjang dan berkesinambungan. Dari pendapat para ahli di atas dapat disimpulkan pendidikan luar sekolah adalah pendidikan kegiatan yang terorganisasi dan sistematis, di luar sistem persekolahan yang dilakukan secara mandiri untuk melayani peserta didik dalam rangka mencapai tujuan belajar.

Salah satu cara memberdayakan masyarakat adalah dengan pendidikan non formal yang bertujuan untuk berlatih secara sistematis serta menggali proses belajar pada kelompok masyarakat. Hal tersebut bertujuan untuk meningkatkan kinerja serta kompetensi masyarakat pada pekerjaannya saat ini serta tanggung jawab yang akan datang. Sesuai dengan perannya sebagai pemberdaya masyarakat, sudah semestinya pendidikan nonformal menyediakan berbagai program yang dibutuhkan untuk menyejahterakan masyarakat. Program yang diselenggarakan tersebut harus sesuai dengan kebutuhan serta perkembangan masyarakat pada saat ini, Syamsi (2010).

Pada dasarnya, pemberdayaan masyarakat melalui pendidikan nonformal dapat terselenggara melalui tahapan tahapan, seperti yang dinyatakan Kindervat terpada Syamsi (2010), yaitu: (1) pengembangan pemikiran; (2) perolehan pemikiran; (3) pengembangan rasa percaya diri; (4) peningkatan kesejahteraan hidup. Menurut Kartika (2015), tahapan tahapan tersebut digunakan untuk perluasan pelayanan pendidikan melalui satuan pendidikan serta programprogram pendidikan nonformal dengan memberikan kesempatan pada masyarakat untuk dapat memelihara, memanfaatkan, serta mengelola kualitas kehidupan masyarakat itu sendiri. Oleh sebab itu, pendidikan nonformal pun harus dikembangkan dengan berpatokan pada apa yang dibutuhkan oleh masyarakat serta tidak mengabaikan tantangan yang ada. Hal tersebut dipercaya mampu memperluas akses bagi masyarakat untuk meningkatkan kualitas hidupnya menjadi lebih baik.

Jadi, kesimpulan yang dapat diambil ialah pemberdayaan masyarakat melalui pendidikan nonformal merupakan suatu cara yang digunakan untuk 
meningkatkan kualitas kehidupan masyarakat menjadi lebih baik melalui berbagai program serta tahapan tahapan.

Menurut Carlzon serta Macauley seperti dikutip oleh Sadu (1998), menyatakan sebuah pemberdayaan yang merupakan suatu pembebasan seseorang dari kontrol ketat maksudnya yaitu memberikan orang kebebasan pada bertanggung jawab terhadap keputusan, ide serta tindakan yang mereka lakukan.

Sementara itu oleh Carver serta Clatter Back pada Riza \& Roesmidi (2006), mendefenisikan pemberdayaan merupakan upaya untuk memberdayakan individu serta memberdayakan mereka untuk mengambil tanggung jawab individu untuk perbaikan diri serta untuk berkontribusi pada tujuan organisasi.

Pemberdayaan secara etimologis berasal dari kata "power" yang merupakan kemampuan atau kekuatan. Berdasarkan definisi di atas, pemberdayaan diartikan sebagai suatu proses menuju pemberdayaan, proses perolehan kekuasaan/kekuatan/kapasitas, proses pemberian kekuasaan/kekuatan/kapasitas dari orang berdaya yang memiliki kekuasaan kepada para sekelompok orang yang belum berdaya, Teguh (2004).

Pemberdayaan masyarakat merupakan proses pemberian semangat kepada sekumpulan individu yang tidak memiliki akses terhadap sumber daya pembangunan untuk menjalani serta mengembangkan kehidupannya, Irmawita (2013). Pemberdayaan masyarakat merupakan kegiatan yang ditujukan kepada masyarakat pada meningkatkan kualitas hidup. Kegiatan Pemberdayaan Masyarakat ini terfokus pada kebutuhan, potensi, serta karakteristik dari masyarakat tersebut.

Pemberdayaan meliputi pengembangan, memperkuat potensi serta tercapainya kemandirian. Pemberdayaan diberikan kepada masyarakat yang tidak berdaya. Selain itu, pemberdayaan juga diberikan kepada masyarakat yang berdaya hingga mencapai kemandirian, Wahyuni (2018).

Dari berbagai sumber yang ada, pemberdayaan dapat disimpulkan sebagai suatu upaya yang akan dilaksanakan oleh satu orang atau kelompok melalui berbagai kegiatan memberikan keterampilan, mengembangkan pengetahuan, pelatihan atau potensi untuk mendukung terciptanya kemandirian, serta 
pemberdayaan masyarakat pada hal ekonomi, sosial, budaya serta pendidikan untuk membantu menyelesaikan berbagai masalah yang dihadapi.

Menurut Broling (1989) "life skills" merupakan interaksi berbagai pengetahuan serta kecakapan yang sangat penting dimiliki oleh seseorang sehingga mereka dapat hidup secara mandiri. Dalam arti lain, life skill disini ialah kemampuan yang dimiliki seseorang untuk memberdayakan hidupnya yang diperoleh dari pendidikan formal maupun non-formal, bisa berupa workshop, media cetak, atau bahkan semua hal yang terkait ilmu yang mengandung kajian tentang lifeskill.

\section{Pembahasan}

1. Workshop sebagai Wadah Dalam Meningkatkan Pengetahuan dan keterampilan Player

Pada dunia game online dalam hal ini PUBG Mobile, sudah banyak komunitas -komuitas didalam naungan Federasi E-Sports Indonesia (FEI) yang sudah mempunyai workshop sebagai wadah bagi player amatir untuk mejadi professional player yang kompetitif, dimana dalam hal ini workshop menyediakan pelatihan khusus bagi para player - player amatir dalam bentuk pemberian teori seputar game tersebut, kemudian latihan intens pada game tersebut, dan semua hal terkait kompetitif serta prospek dibahas dalam worksop tersebut. Kegiatan workshop ini dilakukan dengan cara memberikan materi seputar game tersebut secara mendalam dan menyeluruh serta dari berbagai aspek. Mulai dari strategi, rotasi, gameplay serta peningkatan mental dalam berkompetitif. Agar harapannya output dari workshop tersebut bisa menghasilkan player - player dengan kemampuan diatas kualifikasi rata - rata yang siap untuk terjun ke dunia kompetitif nantinya.

2. Scrim Workshop Sebagai Wadah Dalam Meningkatkan Pengetahuan Dan Keterampilan Player

Scrim adalah bentuk latihan khusus antar player game PUBG didalam class private game tersebut, dimana kegiatan atau agenda ini diselenggarakan secara rutin dan peserta membayar untuk mengikuti kegiatan tersebut untuk setiap tim 
yang mereka bela dalam hal ini tanggung jawab masing - masing komunitas. Kegiatan ini adalah salah satu bentuk praktek dari teori yang sudah didapat selama workshop berlangsung, pada kegiatan ini 100 orang player yang tergabung pada workshop, teraining, dan private class ditandingkan secara besamaan dalam sebuah permainan, terdapat 2 orang spectator atau pengamat dalam hal ini coach / instruktur game guna menganalisa game play dan mengkoreksi apa - apa saja yang kurang dari masing - masing player / tim yang yang tergabung dalam kegiatan ini. Yang pada setiap akhir kegiatan cri mini di adakan evaluasi gameplay masing - masing player dari game tersebut. pada intinya semua arahan strategi untuk memenangkan game tersebut dilakukan pada kegiatan scrim, kegiatan ini bisa dilakukan secara independent untuk komunitas itu sendiri ataupun bisa juga dilakukan antar komunitas. Guna untuk persiapan komptitif dan peningkatan kemampuan.

3. Player Game Online Workshop Sebagai Wadah Dalam Meningkatkan Pengetahuan dan keterampilan Player

Player game online kompetitif merupakan bentuk life skill di era teknologi informasi serta komunikasi modern. Player game online merupakan suatu integritas dipada diri seseorang yang bisa dimanfaatkan untuk memenuhi kebutuhan finansial. Player game online merupakan individu yang profesional pada bidang game. Mereka dapat bermain game online dengan durasi waktu yang cukup lama, supaya kemampuan mereka tersebut dapat "diperjual-belikan" sebagai skill dalam dunia kompetitif. Tidak ada pelatihan khusus bagi seorang player game online, semua keterampilan yang dimiliki pada umumnya merupakan hasil otodidak serta karena terbiasa memainkan game tersebut. Namun kemampuan yang dimiliki seorang player game tersebut bisa saja serta sangat mungkin memiliki prospek yang bagus. Tidak hanya di memenuhi kebutuhan finansial, namun tidak menutup kemungkinan dapat mengukir prestasi pada Platform game tersebut melalui komunitas-komunitas yang berkembang pada era teknologi informasi serta komunikasi modern ini. Dilain sisi, pekerjaan menjadi seorang player game online ini sangatlah menyenangkan, aman dari pandemi, serta bisa menghasilkan uang pada kurun waktu yang relatif singkat. Karena 
selain sebagai sarana untuk mendapat profit dari hasil berkompetisi, kegiatan memainkan game tersebut merupakan wadah bagi player game tersebut untuk menyalurkan hobi serta mengukir prestasi, terlebih pada era digital ini kegiatan bermain game berbasis kompetitif sudah sering diadakan. Tidak hanya tingkat daerah, namun juga ke tingkat nasional bahkan internasional. Banyak sekali komunitas-komunitas game yang sudah terkenal di dunia PUBG Mobile yang menampung para player game tersebut guna untuk terjun ke dunia kompetitif diantaranya merupakan BIGETRON E-Sports , REX REGUM QEON, EVOS ESports, 69 E-Sports serta masih banyak lagi. Komunitas-komunitas game tersebut ada di setiap region daerah di Indonesia. Didalam komunitas ini semua player menjalani sesi latihan yang sangat sering guna untuk meningkatkan kemampuan bermainnya, Tentunya untuk bergabung dengan komunitas game tersebut tidak sembarang orang, melainkan komunitas tersebut memiliki kualifikasi serta persyaratan untuk kemudian bisa bergabung menjadi anggota komunitas. Diantaranya statistik player, level akun player, prestasi player selama memainkan game tersebut, serta tak terkecuali Attitude didalam maupun diluar game. Jadi dapat disimpulkan bahwa game online pada era digital ini tidak lagi bisa kita pansertag sebelah mata sebagai kegiatan yang hanya membuang-buang waktu, namun bisa juga menghasilkan profit, bisa menjadi pekerjaan, bisa menyalurkan hobi, serta juga mengukir prestasi.

4. E-Sports Workshop Sebagai Wadah Dalam Meningkatkan Pengetahuan dan keterampilan Player

E-Sports atau olahraga berbasis teknologi elektronik modern merupakan suatu istilah dalam dunia game yang kompetitif untuk permainan game yang dimainkan lebih dari satu orang, bisa berasal dari pemain amatir maupun pemain professional. Platform ini mewadahi semua kalangan untuk menyalurkan kemampuan pada dunia kompetitif guna mencapai prestasi serta bahkan tidak menutup kemunginan dapat memenuhi kecukupan pada hal finansial. 


\section{SIMPULAN}

Tingginya antusiasme generasi muda terhadap perkembangan teknologi modern yang dalam hal ini game online harus disikapi secara positif oleh masyarakat. Dari tingginya minat dan antusias para genersai muda yang dalam hal ini player game online bisa menjadi peluang usaha dalam situasi ekonomi yang sulit pada masa sekarang ini. Beberapa program yg dapat di tawarkan dalam memberikan pendidikan dan latihan peningkatan pengetahuan dan keterampilan player diantaranya, Workshop, SCRIM Workshop, Player Game Online Workshop, dan E-Sprort center.

\section{DAFTAR PUSTAKA}

Refrianti, R. (2020). Hubungan Status Sosial Perkonomian dengan Motivasi Kerja Ibu Rumah Tangga Pada Usaha Kerupuk Cabe Uniang Kelurahan Anduring Kecamatan Kuranji, Kota Pasertag (Doctoral dissertation, Universitas Negeri Padang).

Jailani, M. (2019).Hubungan Status Sosial Perekonomian Orang Tua Terhadap Motivasi Kepada Anak Untuk Berwirausaha. Pedagogik: Jurnal Pendidikan, 14(1), 35-42.

Nurjannah, S. L. (2014). Hubungan Antara Status Sosial Perkonomian Dengan Motivasi Orang Tua Menyekolahkan Anak di PAUD Smart Kid serta PAUD Sahabat Anak kamu Kecamatan Dau. Malang: Fakultas Psikologi UIN.

Suciningrum, N. P., \& Rahayu, E. S. (2015).Pengaruh Status Sosial Perekonomian Orang Tua serta Motivasi Belajar Tehadap Minat Untuk Melanjutkan Studi Ke Perguruan Yang Lebih Tinggi Pada Kelas XI di SMA Pusaka 01 Jakarta. Jurnal Pendidikan Ekonomi Serta Bisnis (JPEB), 3(1), 1-21.

Wahyuningsih, I., \& Yulianto, A. (2020).Pengaruh Status Sosial Perekonomian Orang Tua serta Praktik Industri Dunnia Kerja Melalui Motivasi Kerja terhadap Kesiapan Kerja. Economic Education Analysis Journal,9(2), 532-551. 